\title{
Utjecaj migracija na objektivne uvjete života obitelji maloljetnih delinkvenata
}

\author{
Tatjana Vujović \\ Filozofski Fakultet, Nikšić, Studijski program za sociologiju, Univerzitet Crne \\ Gore, Crna Gora \\ e-mail: tanja_vujovic@yahoo.com
}

\begin{abstract}
SAŽETAK Intenzivno doseljavanje seoskog stanovništva u gradovima Crne Gore tokom druge polovine 20. vijeka, neravnomjeran razmještaj, problemi u adaptaciji, loši stambeni uvjeti, nezaposlenost kao i evidentna ispoljavanja ekonomske, socijalne i moralne krize imali su za posljedicu pojavu brojnih socio-patoloških pojava kao što su: kriminalitet, zlouporaba psihoaktivnih supstanci, suicid, prosjačenje, dezintegracija obitelji. Cilj ovog znanstvenog rada bio je sagledati da li postoji statistički značajna razlika u objektivnim uvjetima života u obitelji kod delinkvenata koji su migrirali i onih koji nisu migrirali. Neka istraživanja pokazuju da su objektivni uvjeti života u obiteljima maloljetnih delinkvenata lošiji od uvjeta u obiteljima nedelinkvenata te mogu biti rizični za pojavu delinkventnoga ponašanja. Podaci dobijeni ovim istraživanjem pokazuju da postoji statistički značajna razlika između maloljetnih počinitelja kaznenih djela i onih koji to nisu u većini varijabli koje govore o objektivnim uvjetima života u obitelji. Taj rezultat upućuje na to da se migracije mogu promatrati kao rizični utjecaji na objektivne uvjete života u obitelji, te na taj način posredno utječu na poremećaje u ponašanju. Maloljetnicima koji dolaze iz migrantskih obitelji i njihovim obiteljima potrebna je ciljana pomoć u društvu primitka, kako bi im se što više olakšala prilagodba na novu sredinu te zdravo funkcioniranje i razvoj.
\end{abstract}

Ključne riječi: migracije obitelji, socio-patološke pojave, objektivni i subjektivni uvjeti života, antisocijalno ponašanje, agresija.

\section{Uvod}

Kao i druga živa bića, čovjek nastoji ostati ondje gdje je rođen, dok nije zbog nekih razloga prinuđen na seljenje. Postoje brojne definicije i teorije o migracijama i brojne klasifikacije migracija. Da bi neko kretanje bilo migracija ono treba biti označeno promjenom stalnoga prebivališta promjenom koju karakterizira neko razdoblje u kojem se ona događa, zatim neka udaljenost koju prelazimo da bi smo promijenili mjesto prebivališta, ta promjena mora biti planirana i sa namjerom, može biti pojedinačni čin ili čin grupe i obilježava je prijelaz iz jedne sociokulturne sredine u drugu.

Sa modernizacijom povećana je i ljudska mobilnost te utjecaj ekonomskih čimbenika na seljenje. Dolazi do eksplozivnog rasta gradova. U zemljama u razvoju go- 
dišnje u gradove migrira 20 do 30 miliona siromašnih ljudi. Prema Stakleru (Stakler, 2000.:92), proporcija stanovništva svijeta u razvitku koji živi u gradskim područjima dramatično raste: u gradovima je 1960. godine živjelo 22\% stanovništva, 1994.godine već 37\% stanovništva, a 2025. mogla bi doseći 57\%. Prema projekcijama UN-a, prognoze npr. za Njemačku, bez imigracije od 1990.do 2030. godine pokazuju da bi 14 milijuna ljudi više umrlo nego što bi se rodilo. Pod pretpostavkom da uvjeti zapošljavanja ostanu nepromijenjeni, a stopa aktivnosti za domaću i stranu populaciju ista, godišnja potražnja za neto imigracijom prosečno bi dosezala 400.000 ljudi. Stoga se postavlja pitanje može li i treba li takav razvitak biti izbjegnut daljnjom neto imigracijom. Da bi nadoknadile sve veći starosni teret između 2010. i 2020.godine, evropske bi zemlje trebale primiti 47 milijuna osoba radne dobi, a to je oko 10 puta više od ukupnoga priljeva u desetljeću 1985.-1995. Takvu imigraciju teško je i zamisliti, zbog nemogućnosti stvarne kontrole poželjnih tokova i društvenih problema oko integracije postojećih stranih populacija (Angenendt, 1999.:30).

Pretežno zbog posla, pojedinci - ali i obitelji mijenjaju mjesto boravka i sele se u drugo mjesto, drugi grad dio zemlje ili drugu zemlju, kontinent. Pri tome su migranti i njihove obitelji izloženi brojnim stresnim činiocima u prilagodbi novim uvjetima života. Prelazak sa sela u grad praćen je dugom neprilagođenošću, u gradu nestaje socijalna kontrola, razvija se disperzivnost svih društvenih skupina. Mladi ljudi često kao pratnja roditeljima migrantima, pogođeni su brojnim utjecajima (dolazak u novu životnu sredinu, nova škola, novi vršnjaci, novi zahtjevi u novoj sredini, norme ponašanja, život sa jednim roditeljem) mogu dovesti do ozbiljnih promjena u životnim uvjetima, a time do većeg rizika za pojavu poremećaja u ponašanju. Prilagodba na novu sredinu ovisi o nekim osobnim karakteristikama roditelja i djece migranata, okolnostima migriranja, ali i o odnosu sredine primitka prema doseljenicima. Promjena mjesta boravka predstavlja stres i za roditelje, pa takva situacija može pogoršati partnerske odnose i dovesti do brojnih socio-patoloških pojava kod roditelja kao što su: alkoholizam, narkomanija, asocijalno ponašanje. Stres uzrokovan promjenom mjesta boravka, ako ga prate negativne okolnosti vezane za obiteljsku situaciju i uvjete života, povećava rizik za poremećaje u ponašanju kod mladih.

Tokom druge polovine 20. vijeka Crna Gora je bila izložena snažnom procesu demografske tranzicije. Od zemlje sa visokom stopom nataliteta, mortaliteta, sa visokim rastom ukupnog stanovništva, sa ravnomjerno raspoređenim stanovništvom transformirala se u zemlju sa niskim ukupnim rastom stanovništva, sa niskim stopama nataliteta, porastom mortaliteta, konfliktnim razmještajem stanovništva i ubrzanom urbanizacijom, čije su tendencije dugoročne (Bakić, Mijanović i Doderović, 2010.). Razlozi za iseljavanja na relaciji selo-grad javili su se kao posljedica industrijalizacije i dinamičkog razvoja grada. Sva investicijska ulaganja uglavnom su bila usmjerena prema industriji i turizmu, dok su ulaganja u razvoj poljoprivrede bila zanemarljiva. Lokacija turističkih i industrijskih kapaciteta, bila je vezana za općinska naselja i općinske centre, te su oni nudili radna mjesta i zapošljavanje. Osim toga, gradska naselja i općinski centri se ubrzanije opremaju društvenim servisima iz oblasti zdravstva, školstva, te nude školovanje i zapošljavanje, što je izazivalo intenzivne 
odlaske sa sela, što je neminovno povećavalo njihovu imigracijsku privlačnost. Napuštanje sela opravdavalo se pored ekonomskih razloga, duhovnom nadgradnjom, kao i razlozima što je život u selu onemogućavao mlade ljude da u njemu nađu svoje mjesto i funkciju. Ta kretanja dovela su do populaciono demografske eksplozije crnogorskih gradova, pa je nivo urbanizacije sa tog aspekta od 21,3\% u 1948. godini porastao na 58,3\% u 1991.godini i 61,9\% u 2003.godini. Tokom dužeg perioda crnogorsko selo bilo je čuvar tradicije i običaja, proizvođač hrane. Medjutim od 1948. do 2003. seosko stanovništvo je opalo sa $78 \%$ na 38\%. U tom periodu 29 sela ostalo je bez stalnih stanovnika, do 25 stanovnika bilo je u 260 sela. Na drugoj strani ubrzano je rastao apsolutni broj stanovnika gradskih naselja. Tako u 10 najvećih gradova Crne Gore (Podgorica, Nikšić, Pljevlja, Bijelo Polje, Cetinje, Bar, Herceg Novi, Berane, Budva, Ulcinj) živjelo je 307,062 građana. U periodu od 1991. do 2003. došlo je do velikih disproporcija u prostornom razmještaju stanovništa. 2003.godine na 4.462 $\mathrm{km}$ sjevernog regiona živjelo je 10\% stanovnika Crne Gore. U središnjem regionu 45,1\% stanovništva., u primorskom regionu živjelo je 23,5\% stanovništva, u Općini Podgorica 27,3\% stanovništva Crne Gore.

Migracije stanovništva selo-grad mogu se tretirati dvojako i pozitivno i negativno. Pozitivno zato što se selo u jednom vremenu opće nerazvijenosti oslobađalo viška radne snage (Raonić, 2010.:511). Nova radna mjesta u industriji i uslužnim djelatnostima uticala su na odliv prekobrojnog seoskog stanovništva, čime je otpočeo proces smanjenja seoskog stanovništva, ali i proces lažnog zapošljavanja stanovništva. Tako da je bijeg od ,,seoske bijede mnoge doveo u jedva podnošljivu, pa čak i goru bijedu gradskog života“. Migracije sa sela izazvale su i brojne negativne posljedice, kako u selima tako i u gradovima. Ogroman broj sela ostao je bez radno-sposobnog stanovništva, tako da je u njima u potpunosti ovladala senilizacija radne snage. Intenzivno doseljavanje seoskog stanovništva u gradovima Crne Gore i neravnomjeran razmještaj imalo je za posljedicu pojavu brojnih socio-patoloških pojava kao što su: kriminal, zloupotreba psihoaktivnih supstanci,

Postoje različita gledišta istraživača kad je u pitanju povezanost migracija i kriminaliteta.

Neka smatraju da teza o migrantima kao kriminalcima stoji, dok druga drže da je predrasuda o migrantima kao kriminalcima pogrešna. Studija Lyncha i Simona (Mesić, 2002.), u kojoj su kros analizom u 7 zemalja, istraživali je li teza o imigrantima kao kriminalcima točna, pokazala je da u nekim zemljama veliki broj počinitelja kriminalnih djela jesu imigranti te da to utječe na javnu predodžbu o imigrantima kao kriminalcima. Brojne analize u raznim zemljama su pokazale da se kriminalitet kao osobita društvena pojava na prilično specifičan način javlja u gradskim i seoskim sredinama. To se može primijeniti na kriminalitet maloljetnika, koji se tretira kao pretežno urbana pojava (Singer i sur., 2002).

Analize su pokazale da postoji visoka korelacija između razine ekonomskoga razvoja i maloljetničke delinkvencije. Što je neka regija razvijenija, to je i kriminalitet maloljetnika u njoj izrazitiji. Međutim, uzroci socio-patoloških pojava općenito, pa$$
\text { 政 }
$$ 
tako i kriminaliteta mladih ne mogu se tražiti u urbanizaciji i industrijalizaciji kao trendovima društvenoga razvoja, izvan konteksta društveno-ekonomskoga položaja žitelja tih sredina. Ekonomski razvoj ne može se smatrati neposrednim čimbenikom odgovornim za to ponašanje. Ulogu posrednika veze imaju neke treće varijable, manifestne ili latentne, koje potiču ili razvoj ili delinkvenciju.

U Crnoj Gori, kada je riječ o sagledavanju epidemiološke slike maloljetničke delinkvencije, moramo se osloniti na statističke podatke kojima raspolažu razne ustanove kao što su: policija, sud, Centar za socijalnu srb i Statistički zavod. Udio maloljetnika u ukupnom broju osuđivanih jest oko 40\% i tek od 2010. je malo opao. Maloljetnici najčešće počinjaju kaznena djela protiv imovine, teške krađe, a 2011. i 2012. i kaznena djela zlouporabe droge. Punoljetni počinitelji kaznenih djela na prvom su mjestu po imovinskim deliktima, zatim kaznenim djelima protiv bezbjednosti javnog saobraćaja, te kaznena djela protiv života i tijela (Statistički godišnjak Crne Gore, 2010., 2011., 2012. i 2013.).

Autori Martinez i Forgatch (2002.) proveli su istraživanje na uzorku od 238 samohranih majki i njihovih sinova u dobi od 7 do 10 godina kojim su utvrdili da između ostalog, promjene u obitelji kao što su: promjene u ekonomskom statusu, zaposlenju, geografskoj pokretljivosti obitelji utječu na obrazovni uspjeh dječaka, poremećaje u ponašanju i lošiju emocionalnu prilagodbu kod dječaka. M. Mejovšek (1994.) u svojem istraživanju odnosa u obitelji i drugih obilježja obitelji nasilnih i nenasilnih delinkventa na uzorku od 606 obitelji maloljetnih počinitelja nasilnih delikata i 592 obitelji maloljetnih počinitelja nenasilnih delikata između ostalog zaključuje da je nasilničko ponašanje fenomen urbanih sredina, kao i to da su nasilni delinkventi učestalije živjeli izvan roditeljskoga doma. Cajner Mraović i sur. (1996.) na uzorku od 412 maloljetnih počinitelja kaznenih djela na području Županije bjelovarsko - bilogorske potvrđuje da maloljetni delinkventi iz doseljenih i nedoseljenih obitelji statistički značajno razlikuju s obzirom na školovanje, socioekonomski status i obiteljsku patologiju. Maloljetni delinkventi iz doseljenih obitelji imaju nepovoljniji ekonomski i stambeni status, češće se suočavaju sa socio-patološkim pojavama u obitelji i imaju više problema u školi. Ti rezultati upućuju na to da je situacija u migrantskim, tj. doseljenim obiteljima rizičnija sa aspekta poremećaja u ponašanju i maloljetničke delinkvencije.

Ovo istraživanje pokušava dovesti u vezu migracije i jedan dio kriminaliteta koji se odnosi na mlade u Crnoj Gori, dakle specifično područje kriminaliteta: delinkvenciju mladih u nas. Nastoji se provjeriti razlikuju li se maloljetni delinkventi na područjima obiteljskoga života s obzirom na podatak jesu li migrirali ili ne, te u kojim je aspektima obiteljskoga života ta razlika značajna. Na taj način moglo bi se planirati područje rada s delinkventima i obiteljima koje migriraju.

\section{Metoda}

Istraživanje, rezultati kojega će biti prikazani u ovom radu, usmjereno je na populaciju adolescenata, počinitelja kaznenih djela na području Crne Gore. 


\section{Cilj istraživanja}

Cilj je istraživanja utvrditi postoji li statistički značajna razlika između ispitanika migranata i neemigranata u varijablama koje se odnose na objektivne uvjete života u obitelji u kojima žive.

Polazna je hipoteza da će postojati statistički značajna razlika između ispitanika migranata i neemigranata u većini promatranih varijabli.

\section{Uzorak}

Istraživanje je provedeno metodom slučajnog odabira na uzorku od 115 delinkvenata. Svi ispitanici ovog istraživanja bili su adolescenti starosne dobi od 15 do 18 godina. U ispitivanju je učestvovalo 88 muških i 27 ženskih osoba. Uzorak su činili maloljetni delinkventi koji se nalaze na evidenciji Centra za Socijalnu skrb Općine Podgorica i to: maloljetni delinkventi kojima je izrečena odgojna mjera pojačanog nadzora od strane organa starateljstva, kao i maloljetni delinkventi kojima je izrečena zavodska odgojna mjera. Iz uzorka maloljetnih delinkvenata možemo uočiti da je od ukupnog broja od 115 maloljetnih delinkvenata njih 65 (56,52\%) koji nisu mijenjali mjesto prebivališta, a $50(43,47 \%)$ koji jesu.

\section{Mjerni instrumenti}

Osnovni instrument istraživanja bio je nestandardizirani upitnik koji je konstruiran za potrebe obimnog sociološkog istraživanja. Upitnik se sastojao od 98 pitanja. Set pitanja iz upitnika koji se odnosio se na objektivne uvjete života u obitelji poslužio nam je u ovom istraživanju. Upitnikom su obuhvaćene sledeće varijable.

$S$ kim maloljetnik živi - Kriminolozi su se vrlo rano počeli zauzimati za veličinu i sastav obitelji iz kojih dolaze maloljetni delinkventi. Ta su ispitivanja počela još 1923. godine i posebno su izražena u radovima Shawa i McKaya (1923.). Neka istraživanja upućuju na to da sve više maloljetnih delinkvenata dolazi iz potpunih obitelji. (Cajner Mraović, 1997.; Vujović, 2009.). Istraživanje koje je provela Vujović na uzorku od 115 maloljetnih delinkvenata u Crnoj Gori pokazuje da od ukupnog broja maloljetnih delinkvenata njih 66,6\% živi s oba roditelja, 33,04 \% živi sa majkom, 14,79\% samo s ocem.

S koliko osoba maloljetnik živi u domaćinstvu - Strukturu obitelji opisuje podatak o veličini obitelji i broju osoba koje žive u zajedničkom domaćinstvu. Neka istraživanja pokazuju da se veličina porodice pojavljuje kao značajan rizični faktor u porodicama niskog socio-ekonomskog statusa, ali ne i u porodicama sa visokim socio-ekonomskim statusom. (Raine, 1993). Cajner Mraović (1995.:211) pronašla je da većina delinkvenata koji su počinili nasilne delikte žive sa više osoba, dok oni koji počinjaju nenasilne delikte žive većinom u malim domaćinstvima. 
Bračni status roditelja maloljetnika - Istraživanja u Hrvatskoj pokazuju da samo manji postotak delinkvenata (oko 3\%) jesu izvanbračna djeca, što upućuje na podatak da izvanbračnost u Hrvatskoj ne predstavlja otežavajuću okolnost za pojavu delinkvencije. Istraživanje koje je provela Cajner Mraović 2002. pokazuje da je od ukupnoga broja prijavljenih maloljetnika njih 7,2\% rođeno u izvanbračnoj zajednici, a $92,8 \%$ rođeno ih je u bračnoj zajednici.

Svađe i sukobi mecu roditeljima - Novije studije su dosljedne u nalazu da je relativan utjecaj separacije i razvoda roditelja na nastajanje poremećaja u ponašanju velikim dijelom posredovan međuroditeljskim konfliktima, koji prethode, traju za vrijeme i slijede nakon razvoda (Amato, Keith, 1991.). Ispoljavanje fizičke agresije i nasilja među roditeljima je naročito težak oblik obiteljskih konflikata koji se pokazuje snažnim faktorom rizika u razvoju delinkventnoga ponašanja. Istraživanja pokazuju da dječaci koji su odrasli u agresivnim obiteljima pokazuju višu stopu agresije i učestvovanja u antisocijalnim aktivnostima u adolescentnom dobu, nego dječaci koji nisu odgajani u takvim obiteljima (McCord, 1988.).

Položaj djeteta u obitelji - U kriminološkim istraživanjima češće se istražuje redoslijed rođenja djeteta. Istraživanja provedena u Hrvatskoj (Cajner Mraović, 1995.) pokazuju da je najviše bilo najstarije i najmlađe djece kao počinitelja kaznenih djela. Cajner Mraović je također uočila da na agresivne modele ponašanja djeteta ne utječe toliko redoslijed njegova rođenja u obitelji koliko je bitna činjenica postojanje većeg broja braće i sestara.

Školska sprema roditelja - U pravilu obrazovni status roditelja maloljetnih delinkvenata tijesno je povezan s cjelokupnim socioekonomskim statusom obitelji. Istraživanja o obrazovnom statusu roditelja pokazuju da postoji dominacija nižega ili najnižega stupnja obrazovanja (Singer i sur., 2002. i dr.).

Ekonomski status obitelji - Pitanje intenziteta i povezanosti između materijalne situacije i pojave delinkventnoga ponašanja oduvijek je bilo predmetom velikog interesa kriminologa u mnogim zemljama. Britanski znanstvenici Rutter i Madge (1976.) govore o tome da ne postoji uzročno-posljedična veza između siromaštva i kriminaliteta jer su kriminalne stope posljednjih desetljeća u stalnom porastu, unatoč podizanju životnog standarda i ekonomskih prilika većeg dijela stanovništva. Neki autori naglašavaju da je djelovanje lošega materijalnog statusa na delinkventni razvoj djece indirektno povezano negativnim utjecajem na ličnost i ponašanje roditelja, koji su onda manje sposobni da pruže pravilan i poželjan odgoj svojoj djeci (Vujović, 2009.; Kilgore, 2000.). U mnogim slučajevima nizak socio-ekonomski status može djelovati kao čimbenik rizika kako za disfunkcionalno ponašanje roditelja, tako i za probleme ponašanja djece, a može biti i posljedica disfunkcionalnog roditeljskog ponašanja. Singer i sur. (2002.:174) na temelju svojih istraživanja zaključuju da utjecaj ekonomskoga statusa na ponašanje pojedinca ovisi o tome kako on doživljava vlastite imovinske prilike. 


\section{Rezultati i rasprava}

\subsection{Struktura obitelji maloljetnih delinkvenata}

\section{S kim maloljetnik živi}

Podaci dobiveni ovim istraživanjem pokazuju da više od polovine ispitanika živi sa oba roditelja (51,30\%), 24,34\% samo sa majkom, 9,9\% samo sa ocem dok 14,78\% živi s drugima. Maloljetnici migranti koji su se doselili iz drugog grada u nešto većem broju slučajeva žive sa drugima, a kod maloljetnika neemigranata zabilježeno je da češce žive sa oba roditelja. Dobiveni rezultati govore da maloljetnici migranti češce žive sa drugim osobama, moguće je da su njihovi roditelji radni migranti pa njih čuvaju i odgajaju rođaci. Ipak, razlika između migranata i neemigranata s obzirom na to s kim maloljetnik živi nije statistički značajna $(\mathrm{p}=17,31)$ (Tablica 1.). Dobiveni rezultati govore u prilog tome da se potpunost obitelji ne može više promatrati kao rizik za pojavu delinkventnoga ponašanja.

Tablica 1.

Migracije is kim maloljetnik živi

\begin{tabular}{|c|c|c|c|c|c|}
\hline \multirow[b]{2}{*}{ Migracije } & \multicolumn{5}{|c|}{ S kim maloljetnik živi } \\
\hline & $\begin{array}{l}\text { Sa oba } \\
\text { roditelja }\end{array}$ & $\begin{array}{l}\text { Samo sa } \\
\text { majkom }\end{array}$ & $\begin{array}{c}\text { Samo sa } \\
\text { ocem }\end{array}$ & $\begin{array}{l}\text { Živi sa } \\
\text { drugima }\end{array}$ & Ukupno \\
\hline \multirow{3}{*}{$\begin{array}{c}\text { Od rođenja živimo } \\
\text { u Podgorici }\end{array}$} & 39 & 15 & 6 & 5 & 65 \\
\hline & 60 & 53,57 & 9,23 & 7,69 & 100 \\
\hline & 66,10 & 23,07 & 54,54 & 29,41 & 56,52 \\
\hline \multirow{3}{*}{$\begin{array}{c}\text { Doselili smo se } \\
\text { sa sela }\end{array}$} & 13 & 9 & 1 & 2 & 25 \\
\hline & 52 & 36 & 4 & 8 & 100 \\
\hline & 22,03 & 32,14 & 9,09 & 11,76 & 21,7 \\
\hline \multirow{3}{*}{$\begin{array}{l}\text { Doselili smo se iz } \\
\text { drugog grada }\end{array}$} & 7 & 4 & 4 & 10 & 25 \\
\hline & 28 & 16 & 16 & 40 & 100 \\
\hline & 11,86 & 14,28 & 36,36 & 58,82 & 21,7 \\
\hline Ukupno & 59 & 28 & 11 & 17 & 115 \\
\hline \multirow[t]{2}{*}{$\%$} & 51,30 & 24,34 & 9,9 & 14,78 & 100 \\
\hline & 100 & 100 & 100 & 100 & 100 \\
\hline
\end{tabular}

$\chi=202,4, \mathrm{df}=4, \mathrm{p}=17,31$ 


\section{S koliko osoba maloljetnik živi u domaćinstvu}

Podaci u ovom istraživanju pokazuju da najveći broj počinitelja kaznenih djela $27,82 \%$ živi sa pet osoba, 24,34\% živi sa četiri osobe, $15,65 \%$ sa šest ili više osoba, 14,78 \% živi sa tri osobe, 12,17\% sa dvije osobe, 0,86\% živi sa jednom osobom, 5,21 \% živi sa rodbinom, a samo 0,86\% žive sami. Maloljetnici migranti koji su se doselili sa sela zastupljeniji su u odnosu na neemigrante u kategoriji života sa šest i više osoba. Maloljetnici koji nisu mijenjali mjesto boravka zastupljeniji su u kategoriji života sa tri ili četiri osobe. Hi-kvadrat test pokazuje statistički značajnu razliku između ispitanika migranata i neemigranata s obzirom na broj osoba sa kojima maloljetnik živi u domaćinstvu ( $\mathrm{p}=0,040)$ (Tablica 2.). U većim obiteljima, na roditelje pada veći teret osiguravanja egzistencije, ali i odgoja djece, a to povećava rizik za pojavu delinkventnoga ponašanja. U migrantskim porodicama dodatno otežava situaciju i potreba da se uklope u novu sredinu.

Tablica 2.

S koliko osoba maloljetnik živi u domaćinstvu

\begin{tabular}{|c|c|c|c|c|c|c|c|c|c|}
\hline \multirow[b]{2}{*}{ Migracije } & \multicolumn{9}{|c|}{ S koliko osoba maloljetnik živi u domaćinstvu } \\
\hline & 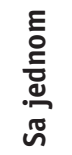 & $\begin{array}{l}: \stackrel{0}{5} \\
\frac{\pi}{0} \\
\stackrel{\sim}{n}\end{array}$ & $\begin{array}{l}5 \\
\stackrel{5}{n} \\
\sim\end{array}$ & 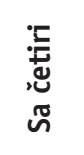 & 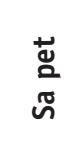 & 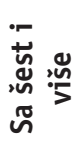 & 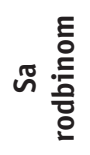 & 壳 & $\begin{array}{l}\text { 음 } \\
\text { 믈 }\end{array}$ \\
\hline \multirow{3}{*}{$\begin{array}{l}\text { Od rođenja } \\
\text { živimo u } \\
\text { Podgorici }\end{array}$} & & 8 & 12 & 19 & 16 & 10 & 615 & 1 & 65 \\
\hline & & 12,30 & 18,46 & 29,23 & 24,61 & 15,38 & 6,15 & 1,53 & 100 \\
\hline & & 57,14 & 70,58 & 59,37 & 57,14 & 55,55 & 66,6 & 100 & 56,52 \\
\hline \multirow{3}{*}{$\begin{array}{c}\text { Doselili smo } \\
\text { se sa sela }\end{array}$} & & 1 & 3 & 7 & 7 & 8 & 1 & & 25 \\
\hline & & 4 & 12 & 28 & 8 & 32 & 4 & & 100 \\
\hline & & 100 & 21,42 & 41,17 & 28,57 & 44,44 & 16,66 & & 27,39 \\
\hline \multirow{3}{*}{$\begin{array}{c}\text { Doselili smo } \\
\text { se iz drugog } \\
\text { grada }\end{array}$} & 1 & 5 & 2 & 6 & 5 & & 1 & & 25 \\
\hline & 4 & 20 & 8 & 24 & 20 & & 4 & & 100 \\
\hline & 100 & 35,71 & 11,76 & 18,75 & 17,85 & & 16,60 & & 27,39 \\
\hline \multirow{3}{*}{$\begin{array}{c}\text { Ukupno } \\
\%\end{array}$} & 1 & 14 & 17 & 32 & 28 & 18 & 6 & 1 & 115 \\
\hline & 0,86 & 12,17 & 14,78 & 27,82 & 24,34 & 15,65 & 5,21 & 0,86 & 100 \\
\hline & 100 & 100 & 100 & 100 & 100 & 100 & 100 & 100 & 100 \\
\hline
\end{tabular}

$\chi=17,31, \mathrm{df}=14, \mathrm{p}=0,040$ 


\section{Bračni status roditelja maloljetnika}

Kada je u pitanju bračni status roditelja ispitanika u ovom uzorku podaci pokazuju da 50,43\% čine djeca rođena u braku, 3,47\% djeca rođena u vanbračnoj zajednici, $32,17 \%$ čine djeca čiji su se roditelji razveli, 5,21\% čine djeca kod kojih je jedan od roditelja umro. Hi-kvadrat test pokazuje statistički značajnu razliku između ispitanika migranata i neemigranata kada je u pitanju ova varijabla. Maloljetnici koji su se doselili sa sela zastupljeniji su među onima čiji je jedan od roditelja umro. Maloljetnici koji su se doselili iz drugog grada zastupljeniji su među onima čiji su se roditelji razveli.

Tablica 3.

Bračni status roditelja maloljetnika

\begin{tabular}{|c|c|c|c|c|c|}
\hline \multirow[b]{2}{*}{ Migracije } & \multicolumn{5}{|c|}{ S kim maloljetnik živi } \\
\hline & 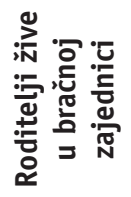 & 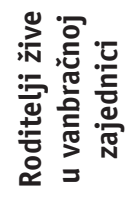 & 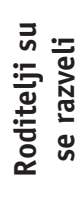 & 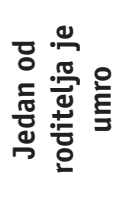 & $\begin{array}{l}\text { 음 } \\
\text { 믈 }\end{array}$ \\
\hline $\begin{array}{l}\text { Od rođenja } \\
\text { živimo u } \\
\text { Podgorici }\end{array}$ & $\begin{array}{c}40 \\
61,53 \\
68,96\end{array}$ & $\begin{array}{c}3 \\
4,61 \\
75\end{array}$ & $\begin{array}{c}13 \\
20 \\
35,13\end{array}$ & $\begin{array}{c}9 \\
13,84 \\
56,25\end{array}$ & $\begin{array}{c}65 \\
100 \\
56,52\end{array}$ \\
\hline $\begin{array}{c}\text { Doselili smo } \\
\text { se sa sela }\end{array}$ & $\begin{array}{c}14 \\
56 \\
24,13\end{array}$ & & $\begin{array}{c}6 \\
24 \\
16,21\end{array}$ & $\begin{array}{c}5 \\
20 \\
83,33\end{array}$ & $\begin{array}{c}25 \\
100 \\
21,73\end{array}$ \\
\hline $\begin{array}{c}\text { Doselili smo } \\
\text { se iz drugog } \\
\text { grada }\end{array}$ & $\begin{array}{c}4 \\
16 \\
6,89\end{array}$ & $\begin{array}{l}4 \\
25 \\
\end{array}$ & $\begin{array}{c}18 \\
48,64\end{array}$ & 72 & $\begin{array}{c}25 \\
100 \\
21,73\end{array}$ \\
\hline $\begin{array}{c}\text { Ukupno } \\
\text { \% }\end{array}$ & $\begin{array}{c}58 \\
50,43 \\
100\end{array}$ & $\begin{array}{c}4 \\
3,47 \\
100\end{array}$ & $\begin{array}{c}37 \\
32,17 \\
100\end{array}$ & $\begin{array}{c}16 \\
5,21 \\
100\end{array}$ & $\begin{array}{l}115 \\
100 \\
100\end{array}$ \\
\hline
\end{tabular}

$\chi=11,92, \mathrm{df}=8, \mathrm{p}=0,015$

\section{Svađe i sukobi među roditeljima}

Kod maloljetnika iz našeg uzorka u 43,47\% slučajeva su veoma često bile prisutne svađe i sukobi među roditeljima, u 32,17\% slučajeva često, u 14,78\% slučajeva po- 
vremeno, rijetko u 8,69\% i nikada u 0,86\% slučajeva. Međutim Hi-kvadrat test ne pokazuje statistički značajnu razliku između ispitanika migranata i neemigranata s obzirom na ovu varijablu.

Tablica 4.

Svađe i sukobi među roditeljima

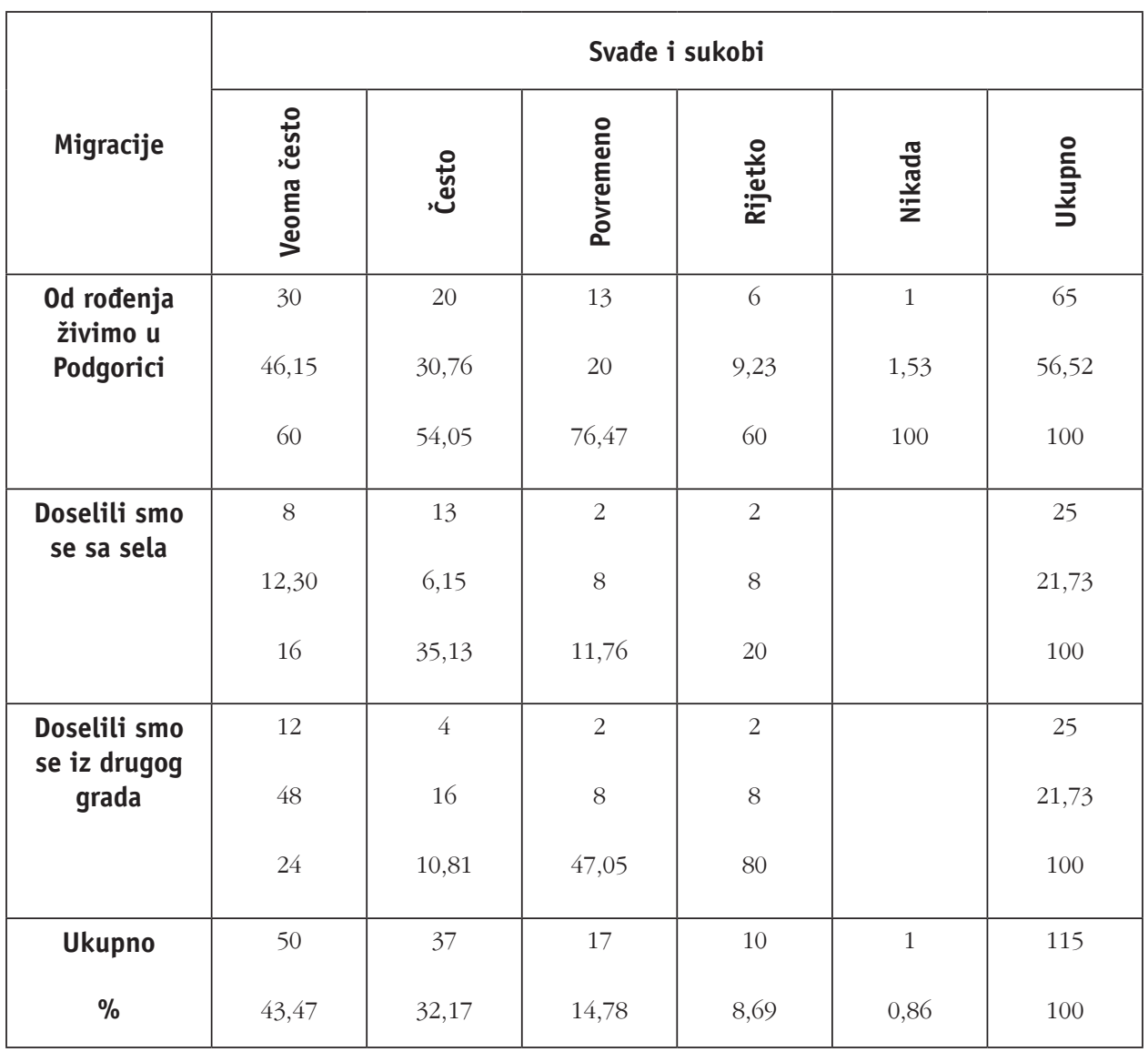

$\chi=6,50, \mathrm{df}=8, \mathrm{p}=0,091$

\section{Položaj djeteta u obitelji}

U 47,82\% slučajeva maloljetni ispitanici bili su najstarije dijete u obitelji. U 25,21\% slučajeva oni su drugorođeno dijete, u 18,26 \% trećerođeno dijete, dok su u 6,95\% slučajeva bili četvrto dijete i u 1,73\% slučajeva petorođeno dijete. Naš uzorak upućuje na to da su upravo prvorođena djeca i najmlađa djeca najugroženija s obzirom na delinkvenciju. Maloljetni migranti zastupljeniji su kao najmlađe dijete. No statističke značajnosti s obzirom na ovu varijablu nema. 
Tablica 5.

Položaj djeteta u obitelji

\begin{tabular}{|c|c|c|c|c|c|c|}
\hline \multirow[b]{2}{*}{ Migracije } & \multicolumn{6}{|c|}{ Položaj djeteta u obitelji } \\
\hline & $\stackrel{2}{2}$ & 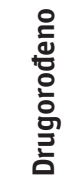 & 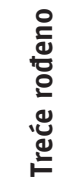 & 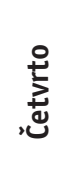 & 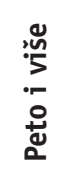 & $\begin{array}{l}\text { 을 } \\
\text { 흘 }\end{array}$ \\
\hline $\begin{array}{l}\text { Od rođenja } \\
\text { živimo u } \\
\text { Podgorici }\end{array}$ & $\begin{array}{c}33 \\
50,76 \\
60\end{array}$ & $\begin{array}{c}18 \\
27,69 \\
62,06\end{array}$ & $\begin{array}{c}10 \\
15,38 \\
47,61\end{array}$ & $\begin{array}{c}4 \\
6,15 \\
50\end{array}$ & & $\begin{array}{c}65 \\
100 \\
56,52\end{array}$ \\
\hline $\begin{array}{l}\text { Doselili smo } \\
\text { se sa sela }\end{array}$ & $\begin{array}{c}7 \\
28 \\
12,72\end{array}$ & $\begin{array}{c}7 \\
28 \\
24,13\end{array}$ & $\begin{array}{c}6 \\
24 \\
28,57\end{array}$ & $\begin{array}{c}4 \\
16 \\
50\end{array}$ & $\begin{array}{c}1 \\
4 \\
50\end{array}$ & $\begin{array}{c}25 \\
100 \\
21,73\end{array}$ \\
\hline $\begin{array}{c}\text { Doselili smo } \\
\text { se iz drugog } \\
\text { grada }\end{array}$ & $\begin{array}{c}15 \\
60 \\
1,81\end{array}$ & $\begin{array}{c}4 \\
16 \\
13,79\end{array}$ & $\begin{array}{c}5 \\
100 \\
23,80\end{array}$ & & $\begin{array}{c}1 \\
4 \\
50\end{array}$ & $\begin{array}{c}25 \\
100 \\
21,73\end{array}$ \\
\hline $\begin{array}{c}\text { Ukupno } \\
\text { \% }\end{array}$ & $\begin{array}{c}55 \\
47,82 \\
100\end{array}$ & $\begin{array}{c}29 \\
25,21 \\
100\end{array}$ & $\begin{array}{c}21 \\
18,26 \\
100\end{array}$ & $\begin{array}{c}8 \\
6,95 \\
100\end{array}$ & $\begin{array}{c}2 \\
1,73 \\
100\end{array}$ & $\begin{array}{l}115 \\
100 \\
100\end{array}$ \\
\hline
\end{tabular}

$\chi=6,50, \mathrm{df}=8, \mathrm{p}=0,19$

\section{Školska sprema roditelja}

Podaci u ovom istraživanju pokazuju da je najviše maloljetnika čiji očevi imaju završenu srednju školu (34,78\%), zatim slijede maloljetnici kojima su očevi bez završene osnovne škole $(32,17 \%)$, nakon njih maloljetnici čiji očevi imaju završenu nižu stručnu spremu, 10,43\%, kod (6,08\%) maloljetnika očevi imaju završenu višu školu, dok kod (10,43\%) maloljetnika očevi imaju završenu visoku školu. Maloljetnici koji su mijenjali mjesto boravka tj. oni koji su se doselili sa sela zastupljeniji su među onima koji imaju očeve sa osnovnom školom, a maloljetnici koji nisu mijenjali mjesto boravka zastupljeniji su među onima čiji očevi imaju višu i visoku stručnu spremu. Hikvadrat test pokazuje statistički značajnu razliku između te dvije skupine ispitanika, što upućuje na to da maloljetnim delinkventima koji migriraju, a naročito onima sa sela nedostaje uzor u vlastitoj obitelji, kada je u pitanju obrazovanje. 
Tablica 6.

Školska sprema oca

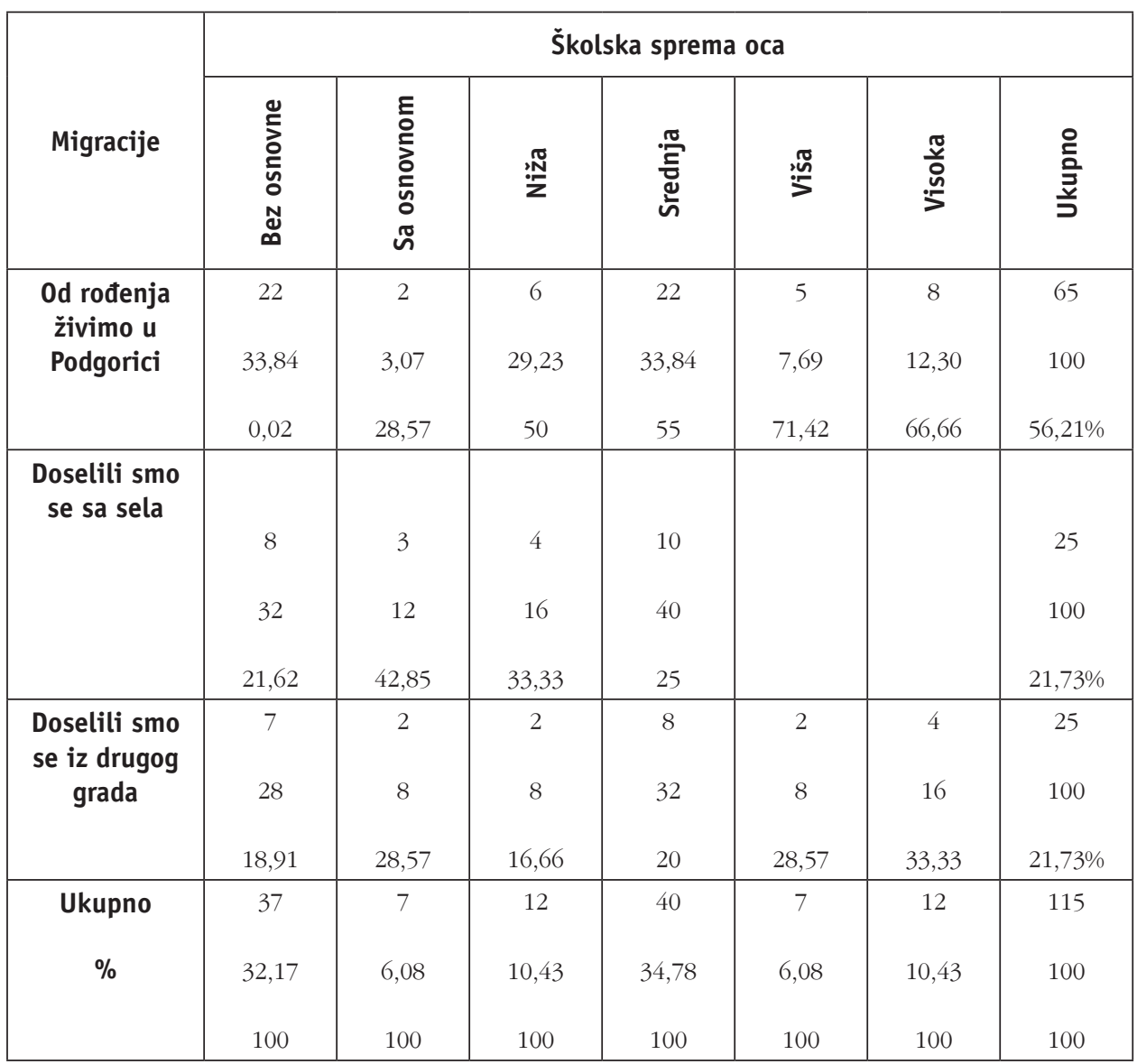

$\chi=18,07 ; \mathrm{df}=4, \mathrm{ss}=5 ; \mathrm{p}=0,09$

Kada je u pitanju školska sprema majke, u istraživanju koje je ovdje provedeno najviše maloljetnika ima majke koje imaju srednju stručnu spremu 31,30\%, slijede oni čije majke imaju završenu osnovnu (33,91\%), zatim ispitanici čije su majke bez osnovne škole, te s manjim udjelom oni čije majke imaju visoku ili višu stručnu spremu, te oni čije majke imaju nižu stručnu spremu $(10,43 \%)$.

Maloljetnici koji nisu migrirali zastupljeniji su među onima čije majke imaju završenu višu i visoku školu, dok su maloljetnici koji jesu migrirali zastupljeniji među onima čije majke imaju završenu osnovnu školu. Postoji statistički značajna razlika između ispitanika koji su mijenjali mjesto boravka i onih koji to nisu s obzirom na ovu varijablu. Ovaj nalaz se može tumačiti veoma ranim stupanjem u brak i potpunim prekidom školovanja ovih žena. Emocionalno nezrele preuzimaju ulogu majke, što se negativno odražava na odgojne postupke. Pretjerana strogost majke i slabe emocionalne veze sa djecom stvaraju kod djece osjećanje straha i nesigurnosti, koje 
nastoje da kompenziraju asocijalnim ponašanjem. Maloljetnici migranti napuštaju školu veoma rano na osnovnoškolskom uzrastu i odaju se asocijalnom ponašanju, što potvrđuju i rezultati ovog istraživanja. To možemo povezati i s prethodnom varijablom očeva obrazovanja i zaključiti da kod maloljetnika migranata na neki način postoji tradicija nižeg obrazovanja u obitelji.

Tablica 7.

Školska sprema majke

\begin{tabular}{|c|c|c|c|c|c|c|c|}
\hline \multirow[b]{2}{*}{ Migracije } & \multicolumn{7}{|c|}{ Školska sprema majke } \\
\hline & 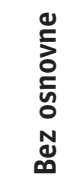 & $\begin{array}{l}E \\
\stackrel{0}{5} \\
\text { D } \\
\text { जू } \\
\text { ñ }\end{array}$ & $\frac{\mathbb{N}}{2}$ & 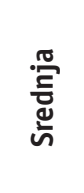 & $\stackrel{\text { : }}{3}$ & $\begin{array}{l}\frac{\pi}{0} \\
\dot{0} \\
5\end{array}$ & $\begin{array}{l}\stackrel{\circ}{\frac{2}{3}} \\
\text { 产 }\end{array}$ \\
\hline $\begin{array}{l}\text { Od rođenja } \\
\text { živimo u }\end{array}$ & 2 & 22 & 9 & 6 & 20 & 6 & 65 \\
\hline Podgorici & $\begin{array}{l}3,07 \\
28,57\end{array}$ & $\begin{array}{l}33,84 \\
56,41\end{array}$ & $\begin{array}{c}13,84 \\
60\end{array}$ & $\begin{array}{l}9,23 \\
66,66\end{array}$ & $\begin{array}{l}30,76 \\
55,55\end{array}$ & $\begin{array}{l}9,23 \\
60\end{array}$ & $\begin{array}{c}100 \\
56,21 \%\end{array}$ \\
\hline $\begin{array}{l}\text { Doselili smo } \\
\text { se sa sela }\end{array}$ & $\begin{array}{l}2 \\
8\end{array}$ & $\begin{array}{l}9 \\
36\end{array}$ & $\begin{array}{l}3 \\
12\end{array}$ & $\begin{array}{c}3 \\
12\end{array}$ & $\begin{array}{c}5 \\
57,14\end{array}$ & $\begin{array}{l}2 \\
8\end{array}$ & $\begin{array}{l}25 \\
100\end{array}$ \\
\hline & 28,57 & 23,07 & 20 & 33,33 & 13,88 & 22,22 & $21,73 \%$ \\
\hline $\begin{array}{c}\text { Doselili smo } \\
\text { se iz drugog } \\
\text { grada }\end{array}$ & $\begin{array}{c}3 \\
12 \\
42,85\end{array}$ & $\begin{array}{c}8 \\
32 \\
20,51\end{array}$ & $\begin{array}{l}3 \\
12 \\
20\end{array}$ & & $\begin{array}{c}6 \\
24 \\
100\end{array}$ & $\begin{array}{c}1 \\
4 \\
11,11\end{array}$ & $\begin{array}{c}25 \\
100 \\
21,73 \%\end{array}$ \\
\hline Ukupno & 7 & 39 & 15 & 9 & 36 & 9 & 115 \\
\hline$\%$ & $\begin{array}{l}6,08 \\
100\end{array}$ & $\begin{array}{c}33,91 \\
100\end{array}$ & $\begin{array}{c}13,04 \\
100\end{array}$ & $\begin{array}{l}7,82 \\
100\end{array}$ & $\begin{array}{r}31,30 \\
100\end{array}$ & $\begin{array}{l}7,82 \\
100\end{array}$ & $\begin{array}{l}100 \\
100\end{array}$ \\
\hline
\end{tabular}

$\chi=12,77, \mathrm{df}=4, \mathrm{ss}=14 ; \mathrm{p}=0,040$

\section{Ekonomski status obitelji}

U uzorku vidimo da 23,47\% ispitanika ima veoma loš ekonomski status 38,26\% ispitanika ima loš, 30,43\% ima niti dobar niti loš, dok samo 7,82\% ispitanika ima dobar. Maloljetnici migranti zastupljeniji su u odnosu na neemigrante među onima čiji je ekonomski status veoma loš i nešto zastupljeniji među onima čiji je ekonomski status loš, dok su ispitanici neemigranti zastupljeniji među onima sa prosječnim statusom. Hi-kvadrat test pokazuje statistički značajnu razliku između ispitanika mi- 
granata i neemigranata u pogledu ove varijable. Maloljetnici koji dolaze iz obitelji koje su mijenjale mjesto prebivališta u novoj sredini stvaraju novi dom, u velikom broju slučajeva su podstanari. Prinuđeni su mjesečno više izdvajati za stanarinu, što ih stavlja u nepovoljniji materijalni položaj. Rezultati istraživanja pokazuju da maloljetnici koji dolaze iz obitelji koje su mijenjale mjesto boravka preseljenje iz jednog u drugi grad u 88,5\% slučajeva imaju dobar materijalni standard. Sve je više migranata koji se upravo zbog svojega visokog obrazovanja sele u drugi grad gdje im se pruža bolji standard i život. To ih stavlja u bolji ekonomski status, ali ne i što se prilagodbe novoj sredini tiče. Njihova djeca u prednosti su pred migrantskom djecom, čiji je ekonomski status obitelji loš, jer im roditelji mogu pružiti više materijalnih sredstava, ali su suočena sa istim problemima vezanima uz prilagodbu na novu sredinu.

Tablica 8.

Migracije i ekonomski status obitelji

\begin{tabular}{|c|c|c|c|c|c|}
\hline \multirow{2}{*}{ Migracije } & \multicolumn{5}{|c|}{ Ekonomski uvjeti } \\
\hline & Veoma loša & Loša & $\begin{array}{l}\text { Niti loša, } \\
\text { niti dobra }\end{array}$ & Dobra & Ukupno \\
\hline \multirow{2}{*}{$\begin{array}{l}\text { Od rođenja žive u } \\
\text { Podgorici }\end{array}$} & 16 & 23 & 25 & 1 & 65 \\
\hline & $59,25 \%$ & $52,2 \%$ & $71,42 \%$ & $11,11 \%$ & $56,52 \%$ \\
\hline \multirow{2}{*}{$\begin{array}{l}\text { Doselili su se sa } \\
\text { sela }\end{array}$} & 8 & 10 & 7 & & 25 \\
\hline & $29,62 \%$ & $22,72 \%$ & $20 \%$ & & $21,73 \%$ \\
\hline \multirow{2}{*}{$\begin{array}{c}\text { Doselili su se iz } \\
\text { drugog grada }\end{array}$} & 3 & 11 & 3 & 8 & 25 \\
\hline & $11,11 \%$ & $25 \%$ & $38,57 \%$ & $88,8 \%$ & $21,73 \%$ \\
\hline \multirow[t]{2}{*}{ Ukupno } & 27 & 44 & 35 & 9 & 115 \\
\hline & $23,47 \%$ & $38,26 \%$ & $30,43 \%$ & $7,82 \%$ & $100 \%$ \\
\hline
\end{tabular}

\section{Zaključak}

Ovaj rad imao je za cilj prikazati koliko migracija utječe na objektivne uvjete života u obitelji maloljetnih delinkvenata u Crnoj Gori. Ovo istraživanje usmjereno je prema promatranju svih važnih elemenata objektivnoga obiteljskog života kod maloljetnih delinkvenata na području Crne Gore i to s obzirom na utjecaj migracija na sferu obiteljskih uvjeta života, za koju je dokazano da je od neopisive važnosti za nastanak delinkventnog ponašanja.

Podaci dobijeni našim istraživanjem pokazuju da postoji statistički značajna razlika između ispitanika migranata i nemigranata u više varijabli vezanih za objektivne uvjete života u obitelji. S obzirom na statistički značajne razlike između ispitanika migranata i neemigranata uviđamo sledeće: 
- da ispitanici migranti u većem broju slučajeva žive sa više osoba;

- da imaju veći broj braće i sestara;

- da su se kod ispitanika migranata koji su se doselili iz drugog grada u većem broju slučajeva roditelji razveli, dok kod migranata koji su se doselili sa sela jedan od roditelja je umro;

- da su kod ispitanika migranata učestalije svađe i sukobi među roditeljima;

- da su im očevi i majke u većem broju slučajeva nižeg obrazovanja, nego kod neemigranata;

- da su kod migranata koji su se doselili sa sela u grad ekonomski uvjeti života lošiji.

Ispitanici migranti statistički se značajno razlikuju od neemigranata u većini varijabli ove skupine. Njihovi objektivni uvjeti života u obitelji pokazuju karakteristike koje predstavljaju pojačan rizik za pojavu delinkventnog ponašanja. Potvrđena je postavljena hipoteza prema kojoj migracija neposredno utječe na objektivne uvjete života u obitelji i može posredno utjecati na pojavu delinkventnoga ponašanja. Evidentno je da su migrantske obitelji suočene s izazovima ili, bolje rečeno, stresnim situacijama u kojima se testira njihova snaga i sposobnost zdrava života i razvoja u novoj sredini. Zavisno od raznih kapaciteta takvih obitelji, promatramo i njihovo normalno funkcioniranje ili pojavu poremećaja i devijantnoga i delinkventnoga ponašanja njezinih članova.

Za rješavanje ovih problema treba postaviti određene ciljeve. Veoma je bitno kvalitetno integrirati demografski razvoj u kontekstu politike cjelokupnog prostornog i društveno ekonomskog razvoja. Planski razmještati i organizirano usmjeravati doseljavanje stanovništva, kako bi se naseljavanje uskladilo sa razmještajem privrednih sadržaja i mogućim otvaranjem novih radnih mjesta, te ublažiti migracione tokove prema Podgorici, i revitalizirati ruralna naselja. Za dulje sagledavanje ovih problema od posebnog značaja bi bila znanstvena istraživanja čvrsto metodološki zasnovana čiji bi osnovni ciljevi bili identifikacija ostalih čimbenika rizika za nastanak kriminaliteta, proučavanje strukture unutarnje migracije sa aspekta starosne dobi i nivoa obrazovanja, utvrđivanje potreba i problema obitelji migranata. Društvena intervencija trebala bi da bude usmjerena na pružanje podrške i pomoći tim obiteljima, u nalaženju stana, posla članovima obitelji, angažiranje stručnih osoba koje bi povremeno dolazile u obitelj. Na taj način bi se moglo donekle utjecati na funkcionalno odgajanje u obitelji. Osnaživanjem ovih obitelji moglo bi se preventivno djelovati na sprečavanje nastanka kriminaliteta njihovih članova.

Potrebno je osmišljavati različite programe prevencije koji bi bili usmjereni na rizične obitelji i kojima bi se pomoglo rizičnim obiteljima u rješavanju njihovih problema i osiguravanju uvjeta za normalan razvoj djece i spriječilo pojavljivanje nastanka poremećaja u ponašanju mladih. Angažiranje svih ovih društvenih subjekata i njihovo preventivno djelovanje, može imati uspjeha ukoliko se ovi složeni društveni fenomeni izuče sa stanovišta cjeline društvenih okolnosti koji ih bitno determinišu. Preventivni programi bi trebalo da obuhvate i rad na restituisanju modela ponašanja koji podrazumijevaju nasilje, rad na restituisanju vrijednosti i načina zadovoljenja potreba. 


\section{Literatura}

1. Amato, P. R. and Keith, B. (1991). Parental divorce and the well-being of children: A meta-analysis. Psychological Bulletin, 110, 26-46.

2. Ajduković, M. i Delale, A. (1999). Stil odgoja u obitelji kao činitelj rizika i zaštite u razvoju poremećaja u ponašanju djece i mladeži, u: Rizični i $i$ zaštitni čimbenici u razvoju poremećaja u ponašanju djece $i$ mladeži. Povjerenstvo vlade RH za prevenciju poremećaja u ponašanju djece $i$ mladeži $i$ zaštitu djece s poremećajima u ponašanju.

3. Angenendt, S. (ur.) (1999). Asylum and Migration Policies in the European Union. Berlin: DGAP.

4. Bakić, R.; Mijanović, D. i Doderović, M (1999). Demografska kretanja. Podgorica: Crnogorska Akademija nauka i umjetnosti.

5. Bošković, M. (2006). Kriminologija. Novi Sad: Univerzitet u Novom Sadu.

6. Cloward, R. A. and Ohlin, L. E. (1961). Delinquency and Opportunity: A Theory of Delinquent Gangs. New York: The Free Press.

7. Cajner Mraović, I. (1995). Poremećaji u ponašanju i obiteljske prilike maloljetnih počinitelja nasilničkih $i$ nenasilničkih krivičnih djela. Zagreb: Visoka policijska škola MUP-a RH i fakultet za defektologiju Sveučilišta u Zagrebu.

8. Cajner Mraović, I. i Šućur Z. (1997). Razlike u socijalnoekonomskom statusu, tijeku školovanja i obiteljskoj patologiji maloljetnih delinkvenata s obzirom na migratornost njihovih obitelji. Hrvatska Revija za rehabilitacijska istraživanja, 33 (1): 1-12.

9. Ignjatović, Đ. (2007). Kriminologija. Beograd: Službeni Glasnik.

10. Jašović, Ž. (1991). Kriminologija maloljetničke delinkvencije. Beograd: Naučna knjiga.

11. Kilgore, K.; Snyder, J. and Lentz, C. (2000). The contribution of parental discipline, parental monitoring, and school risk to early-onset conduct problems African-American boys and girls. Developmental Psybology, 36, 835-845.

12. Siegel, L. and Sena, J. (2000). Juvenile Delinquency. Theory, Practice, Law, Seventh dition. Washington: National Center for Juvenile Justice.

13. Maloljetnici i oružje u Crnoj Gori (2006). Stavovi djece i roditelja prema oružju, parti cipativno, istraživanje, SEESA, South Eastern and Eastern Europe Clearinghouse for the Control of small Arms of light Weapons.

14. Marković, I. (2007). Osnovi kriminologije. Banja Luka: Pravni Fakultet.

15. Martinez, C. R. i Forgatch, M. S. (2002). Adjusting to Change: Linking Family Structure Transitions With Parenting and Boy's Adjustment. Journal of Family Psychology, 16 (2): 107-117.

16. McCord, J. (1998). Parental behavior in the cycle of aggression. Psychiatry, 51, $14-23$

17. Mesi, M. (2002). Međunarodne migracije. Tokovi i teorije. Zagreb: Societas, Zavod za sociologiju.

18. Pušić, Lj. (1997). Grad, društvo, prostor. Beograd : Zavod za udžbenike i nastavna sredstva.

19. Raonić, S. (2010). Crna Gora u xxi stoljeću-u eri kompetitivnosti: Migracije selograd i mogući pravci razvoja. Podgorica : Crnogorska Akademija nauka i umjetnosti. 
20. Raine, A. (1993). The psychopathology of crime. San Diego, CA: Academic Press.

21. Siegel, L. J. and Senna, J. J. (2000). Juvenile delinquency. Theory, Practice and Law. California, Belmont: Wadsworth/Thompson Learning.

22. Stalker, P. (2000). Workers without frontiers. The impact of globalization on International migration. New York: Lynne Reiner Publisher. Inc.

23. Singer, M.; Kovčo Vukadin, I. i Cajner Mraović, I. (2002). Kriminologija. Zagreb: Edukacijsko Rehabilitacijski fakultet Sveučilišta u Zagrebu, Nakladni zavod Globus.

24. Vujović, T. (2009). Od žrtve do delinkventa. Nikšić: Filozofski fakultet, Institut za sociologiju.

25. Vujović, S. (2005). Urbana sociologija. Beograd: Zavod za udžbenike i nastavna sredstva.

26. Zavod za statistiku Crne Gore - Monstat (2011.) Statistički godišnjak 2010. Podgorica: Zavod za statistiku.

27. Zavod za statistiku Crne Gore - Monstat (2011.) Statistički godišnjak 2011. Podgorica: Zavod za statistiku. 
Tatjana Vujović

Faculty of Philosophy Nikšić, Department of Sociology, University of Montenegro, Montenegro

e-mail: tanja_vujovic@yahoo.com

\title{
The Impact of Migration on Objective Living Conditions of Juvenile Delinquents' Families
}

\begin{abstract}
In Montenegro there was an intensive migration of rural population to the cities in the second half of 20th century, followed by uneven population distribution, problems with adapting to new surroundings, poor housing conditions, unemployment and evident manifestation of economic, social and moral crisis. The result were numerous socio-pathological issues such as criminal behaviour, psychoactive substance abuse, suicide, panhandling, family disintegration. The purpose of this study is to find out whether there is a statistically significant difference in objective living conditions of juvenile delinquents' families who migrated and those who did not migrate. Some research shows that objective living conditions which can trigger off delinquent behaviour are worse in juvenile delinquents' families than in families of nondelinquents. The research data indicate a notable difference between juvenile delinquents and non-delinquents regarding most statistical variables on objective living conditions. This leads to the conclusion that migrations can be considered a risky element with indirect impact on behavioral disorders. For this reason, migrant families and especially their young members need help and social acceptance to facilitate their adjustment to the new environment, proper functioning and development.
\end{abstract}

Key words: family migration, socio-pathological issues, objective and subjective living conditions, anti-social behaviour, aggression. 